\title{
Examination of metal mobilization from a gunshot by scanning acoustic microscopy, scanning electron microscopy, energy- dispersive X-ray spectroscopy, and inductively coupled plasma optical emission spectroscopy: a case report
}

\author{
Bukem Bilen ${ }^{1 *}$, Fatma Ates Alkan², Umit Bora Barutcu ${ }^{3}$, Meltem Sezen ${ }^{4}$, Mehmet Burcin Unlu and
} Kamran Aghayev ${ }^{5}$

\begin{abstract}
Background: Projectile foreign bodies are known to cause chronic heavy metal toxicity due to the release of metal into the bloodstream. However, the local effect around the metallic object has not been investigated and the main goal of our study is to examine the influence of the object in close proximity of the object.

Case presentation: A 36-year-old Caucasian woman with one metallic pellet close to her sciatic nerve due to a previous shotgun injury at the gluteal area presented with a diagnosis of recurrent lumbar disk herniation at L4-5 level. A physical examination confirmed chronic neuropathy and she underwent a two-stage surgery. The surgery included removal of the foreign body, followed by discectomy and fusion at the involved level. During the removal of the metallic foreign body, a tissue sample around the pellet and another tissue sample from a remote area were obtained. The samples were analyzed by scanning acoustic microscopy, scanning electron microscopy, and energydispersive X-ray spectroscopy. Lead, chromium, copper, cadmium, iron, manganese, selenium, and zinc elements in tissue, blood, and serum specimens were detected by inductively coupled plasma optical emission spectroscopy.

Conclusions: An acoustic impedance map of the tissue closer to the metallic body showed higher values indicating further accumulation of elements. Energy-dispersive X-ray spectroscopy results confirmed scanning acoustic microscopy results by measuring a higher concentration of elements closer to the metallic body. Scanning electron microscopy images showed that original structure was not disturbed far away; however, deformation of the structure existed in the tissue closer to the foreign body. Element analysis showed that element levels within blood and serum were more or less within acceptable ranges; on the other hand, element levels within the tissues showed pronounced differences indicating primarily lead intoxication in the proximity of the metallic body. We can state that residues of metallic foreign bodies of gunshot injuries cause chronic metal infiltration to the surrounding tissue and induce significant damage to nearby neural elements; this is supported by the results of scanning acoustic microscopy, scanning electron microscopy, energy-dispersive X-ray spectroscopy, and inductively coupled plasma optical emission spectroscopy.
\end{abstract}

Keywords: Metal infiltration, Lead toxicity, Scanning acoustic microscopy, Gunshot injury

* Correspondence: bukem.bilen1@boun.edu.tr

${ }^{1}$ Physics Department, Bogazici University, Istanbul, Turkey

Full list of author information is available at the end of the article

(c) The Author(s). Open Access This article is distributed under the terms of the Creative Commons Attribution 4.0 International License (http://creativecommons.org/licenses/by/4.0/), which permits unrestricted use, distribution, and reproduction in any medium, provided you give appropriate credit to the original author(s) and the source, provide a link to the Creative Commons license, and indicate if changes were made. The Creative Commons Public Domain Dedication waiver (http://creativecommons.org/publicdomain/zero/1.0/) applies to the data made available in this article, unless otherwise stated. 


\section{Background}

Metallic foreign bodies from gunshot injuries are typical in clinical practice. Usually, they require no treatment. However, lead $(\mathrm{Pb})$ release from retained bullets may cause systemic toxicity [1-6]. It is generally accepted that foreign particles embedded in soft tissues become encapsulated and induce no harm to the patient. On the other hand, at specific locations, such as joints, bullets or fragments cause subsequent $\mathrm{Pb}$ wash out and systemic toxicity $[7,8]$. Pb toxicity, caused by these gunshot fragments, has been discussed for many years $[4,9,10]$; however, there is no agreement on the immediate removal of the fragments from the body [11-15]. Even though blood levels are not routinely monitored, a few studies showed increased blood Pb levels $[3,7,15,16]$. It was also reported that increased $\mathrm{Pb}$ concentration provoked a reduction in iron $(\mathrm{Fe})$ and calcium $(\mathrm{Ca})$ concentrations altering the ratios of $\mathrm{Fe} /$ copper $(\mathrm{Cu}), \mathrm{Fe} / \mathrm{zinc}$ $(\mathrm{Zn})$, and $\mathrm{Ca} / \mathrm{Zn}$ not only in blood, but also in hair [17].

Scanning acoustic microscopy (SAM) is a modality capable of obtaining information about the structural and elastic properties of biological samples at microscopic levels. With high-frequency ultrasound signals and without using any stains for the specimens, two-dimensional maps can be obtained within minutes. SAM has two modes of measurement: speed of sound (SOS) and acoustic impedance (AI). SOS mode calculates the sound speed passing through the tissues [18-27], while AI mode calculates the AI of samples $[28,29]$. Use of higher frequencies of 100 to $1200 \mathrm{MHz}$ within this microscope enables resolving cells and organelles [30-37]. Scanning electron microscopy (SEM) is another imaging technique used for investigating specimen surfaces at very high magnifications and even higher resolutions. A focused beam of electrons scans the material surface resulting in signal generations due to beam-sample interaction, which in turn can be collected as images with different contrast mechanisms. Energy-dispersive X-ray spectroscopy (EDS) enables the detection of elements and their distribution within samples. A bombardment of the specimen surface with a focused electron beam causes characteristic X-ray spectrum emission, which then can be used to obtain a local chemical analysis. In principle, using EDS measurements, all elements ranging from beryllium $(\mathrm{Be})$ to uranium (U) can be detected. EDS can be performed in SEM or transmission electron microscopy (TEM) systems. Gunshot residue analyses are done successfully by SEM equipped with EDS $[38,39]$.

The majority of scientific papers related to the long-term effect of gun injuries are focused on systemic effects. However, there is evidence that foreign bodies may cause local effects and damage to anatomical structures in close proximity. This local effect has not been studied in detail so far, and, in this research, we aimed to study the local influence of a bullet close to a sciatic nerve by SAM, SEM, EDS, and inductively coupled plasma optical emission spectroscopy (ICP-OES).

\section{Case presentation}

\section{Surgical technique and sampling}

A 36-year-old Caucasian woman was evaluated with chief complaint of gluteal pain radiating to her leg. Her medical history was remarkable with gunshot injury to the affected leg with multiple pellets dispersed into her pelvis and proximal part of the thigh, as shown in Figs. 1 and 2. She had gunshot injury 20 years ago. She was previously diagnosed as having lumbar disc herniation at L4-5 level. She underwent a previous discectomy outside our institution 2 years ago. A radiological examination revealed the presence of recurrent disc herniation, as well as multiple shotgun bullets in her pelvis and thigh. One of those bullets was deep into the sciatic nerve inside her quadratus femoris muscle.

Electromyography (EMG) showed the presence of chronic sciatic nerve injury. Since it was clinically impossible to distinguish lumbar disc herniation from the sciatic injury, we decided to proceed with removal of the foreign object and neurolysis of the sciatic nerve followed by L4 -5 discectomy and fusion. We decided to perform those procedures in two different settings. The first surgery included access to the sciatic nerve in the upper portion of her thigh and exposing the nerve fibrotic bands around the nerve. The dissection proceeded deep into the nerve within a muscle, where a bullet was found and removed. The distance from the bullets to the nerve was approximately $2 \mathrm{~cm}$. Muscle tissue around the bullets was excised for analysis. For

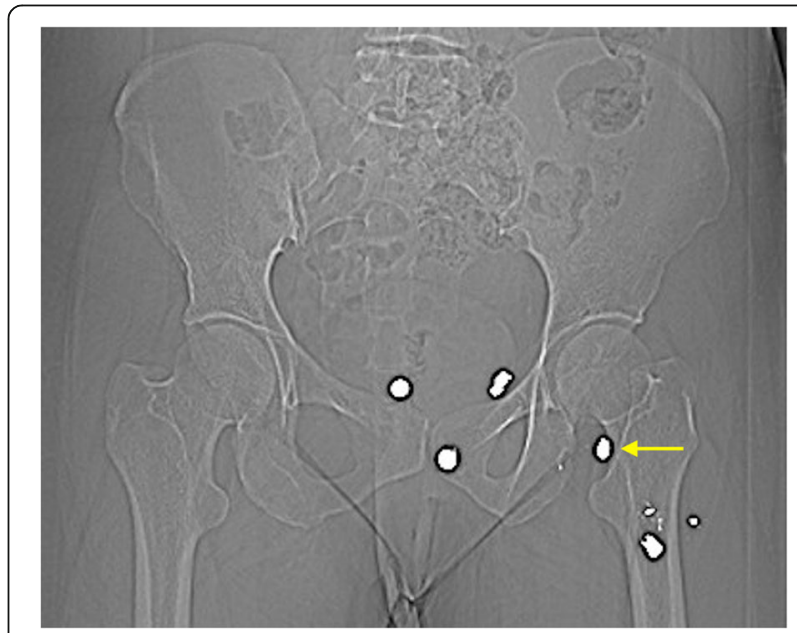

Fig. 1 Preoperative computed tomography scan demonstrating multiple shotgun pellets in the pelvis and upper thigh area. Pellet of interest is marked with yellow arrow 


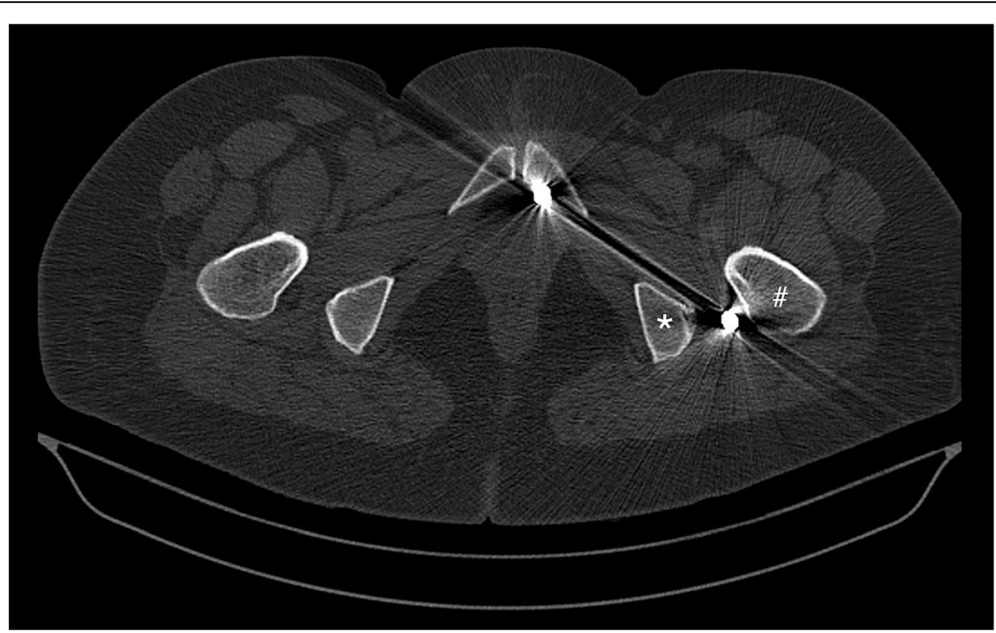

Fig. 2 Preoperative computed tomography scan demonstrating the pellet of interest located between the trochanter major (\#) and ischial tuberosity $\left.{ }^{*}\right)$ close to the course of sciatic nerve

comparison, another specimen was obtained from the gluteal muscle, superficially away from the nerve and all the bullets. Two weeks later, she underwent scheduled L4-5 discectomy and fusion. Her postoperative course was uneventful. On follow-up examination at 6 months, she was essentially symptom free.

\section{SAM}

A scanning acoustic microscope (AMS-50SI) developed by Honda Electronics (Toyohashi, Japan), whose schematic setup is shown in Fig. 3, was used in AI mode. It has a transducer with quartz lens, a pulser/receiver, an oscilloscope, a computer, and a display monitor. An $80 \mathrm{MHz}$ transducer is installed within the microscope, which generates the signals and collects the reflected acoustic waves. Water is the coupling medium between the quartz lens and the substrate. For two-dimensional scans, an X-Y stage, controlled by a computer, is used. An oscilloscope analyzes the reflected signals from both the reference and target material after being collected by the transducer. As a result, acoustic intensity and impedance maps of the region of interest with $300 \times 300$ sampling points are obtained.

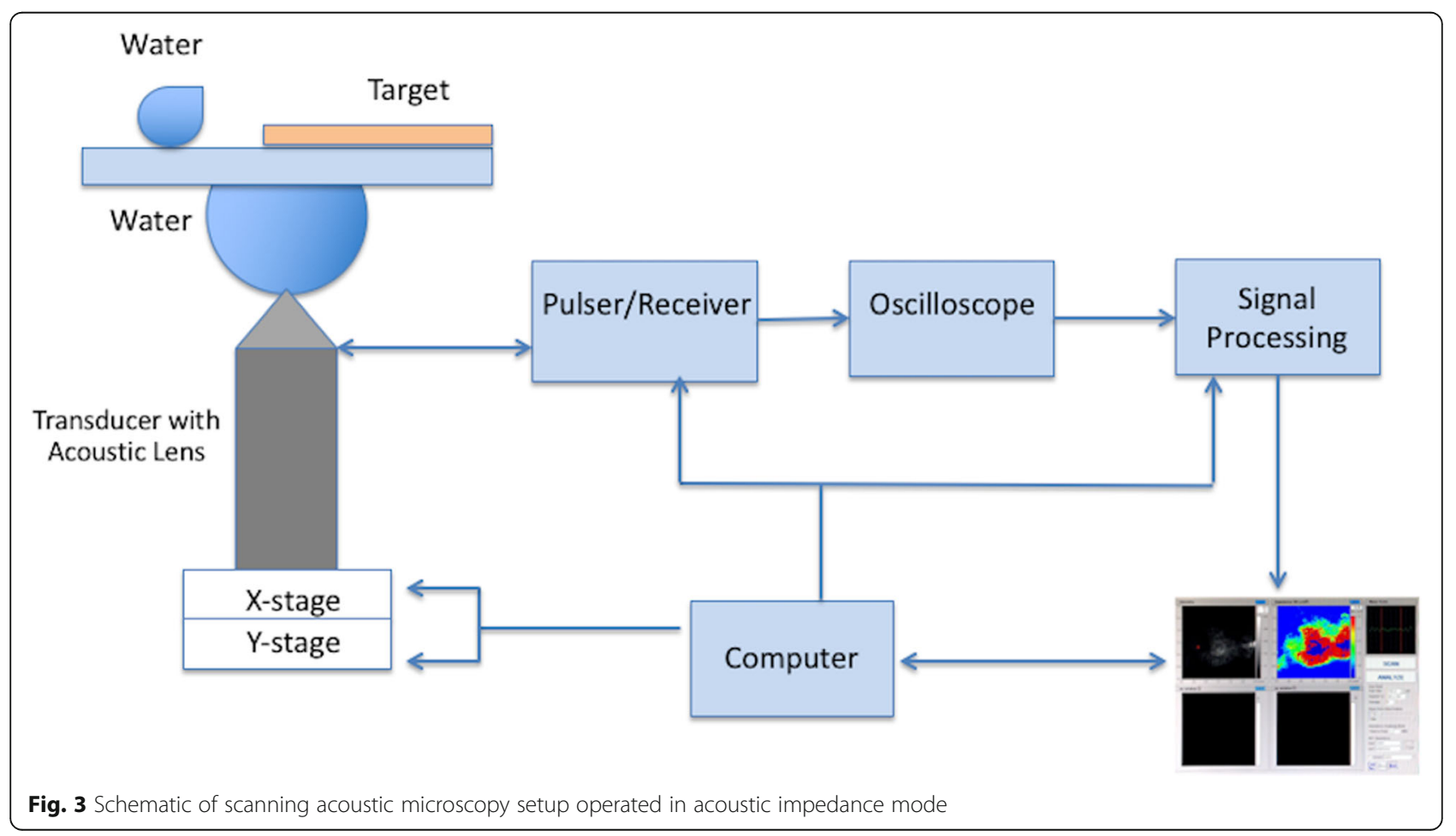


The principle of SAM in AI mode is demonstrated in Fig. 4. Distilled water is widely used as reference. The signal reflected from the target is

$$
S_{\text {target }}=\frac{Z_{\text {target }}-Z_{\text {sub }}}{Z_{\text {target }}+Z_{\text {sub }}} S_{0}
$$

where, $S_{0}$ is the generated signal by the $80 \mathrm{MHz}$ transducer, $Z_{\text {target }}$ is tissue's AI and $Z_{\text {sub }}$ is the polystyrene substrate's AI (2.37 MRayl). The tissue's AI is calculated by combining the reflected signals from the tissue and the reference. The signal reflected from the reference is

$$
S_{\text {ref }}=\frac{Z_{\mathrm{ref}}-Z_{\text {sub }}}{Z_{\text {ref }}+Z_{\text {sub }}} S_{0}
$$

where $Z_{\text {ref }}$ is the AI of water (1.50 MRayl). Then, the target's $\mathrm{AI}$ is written as

$$
Z_{\text {target }}=\frac{1+\frac{S_{\text {target }}}{S_{0}}}{1-\frac{S_{\text {target }}}{S_{0}}} Z_{\text {sub }}
$$

with a constant signal $S_{0}[28]$ generated by the transducer.

\section{SEM and EDS}

Electron microscopy-based imaging and chemical analysis studies were performed in a JEOL JIB-4601 focused ion beam scanning electron microscope (FIB-SEM) multi-beam platform coupled with an Oxford X-MaxN EDS system, as shown in Fig. 5.

\section{Element analysis}

Blood samples were collected in test tubes containing ethylenediamine-tetraacetic acid (EDTA) and no anticoagulant on the day of the first surgery (foreign object removal) prior to the procedure. Then, $2 \mathrm{ml}$ of $20 \%$ trichloroacetic acid (TCA) was supplemented into the blood samples to release the red blood cells (RBC) and other ingredients. The supernatant part was received from blood with TCA by centrifugation at 4000 revolutions per minute (rpm) for 20 minutes for the analysis of $\mathrm{Pb}$ and cadmium $(\mathrm{Cd})$ within total blood. Coagulation of blood samples enabled serum trace element analysis: chromium $(\mathrm{Cr}), \mathrm{Fe}, \mathrm{Cu}$, magnesium $(\mathrm{Mg})$, manganese $(\mathrm{Mn})$, selenium (Se), and $\mathrm{Zn}$. The serum specimen was prepared using Hettich Universal centrifuge by centrifugation at $3000 \mathrm{rpm}$ for 15 minutes, separating from cells immediately after and storing at $-20^{\circ} \mathrm{C}$ until the analysis [40].

After weighing the left sciatic nerve tissue samples, they were digested with $2 \mathrm{ml}$ of $65 \%$ nitric acid $\left(\mathrm{HNO}_{3}\right)$ at $180{ }^{\circ} \mathrm{C}$ in the incubator for 1 hour. Then, $2 \mathrm{ml}$ of $65 \%$

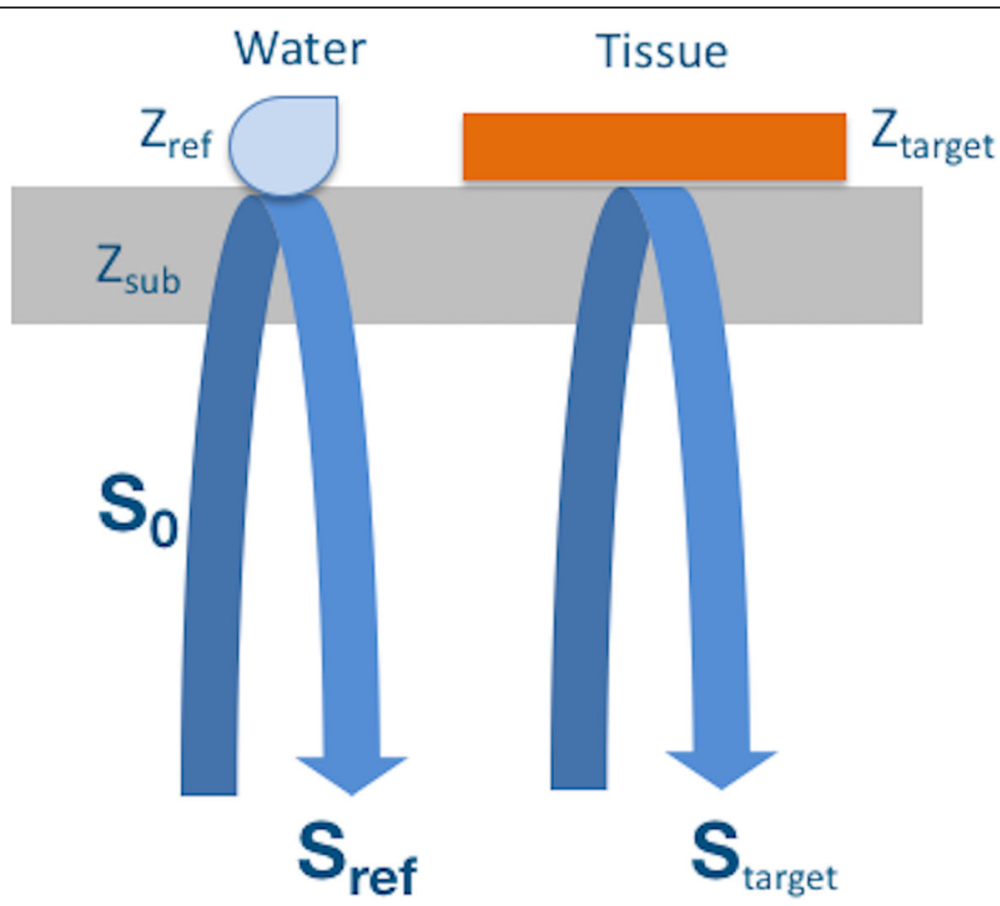

Fig. 4 Principle of scanning acoustic microscopy in acoustic impedance mode. The acoustic waves reflected from the surfaces of water and the tissue are collected by the same transducer and then combined for the calculation of the acoustic impedance of the tissue. $S_{0}$ is the generated signal by the $80 \mathrm{MHz}$ transducer, $Z_{\text {ref }}$ is the acoustic impedance of water, $Z_{\text {sub }}$ is the polystyrene substrate's acoustic impedance, $Z_{\text {target }}$ is tissue's acoustic impedance 

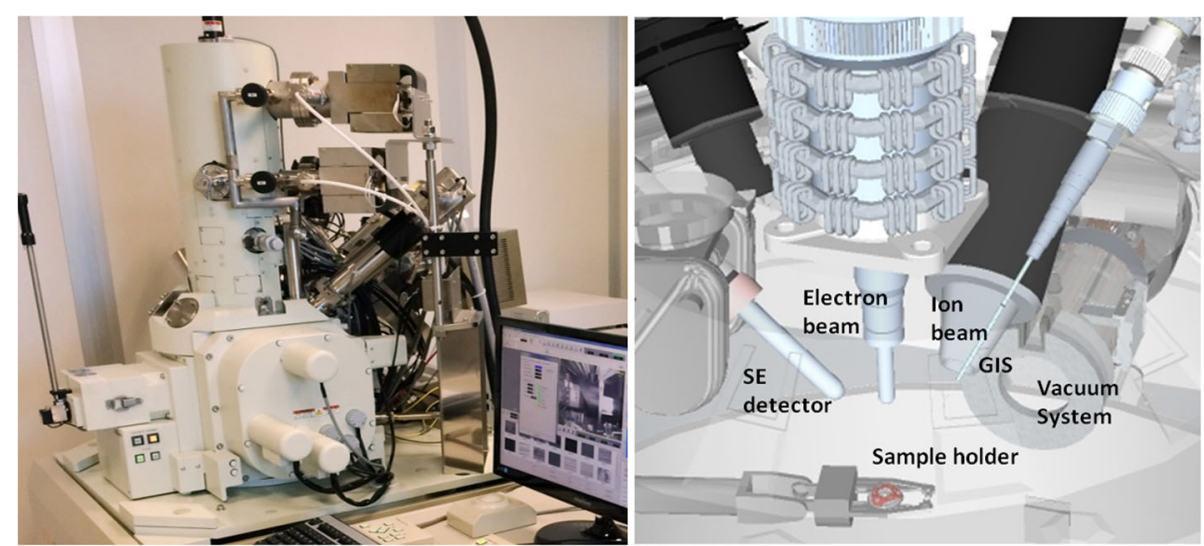

Fig. 5 JEOL JIB-4601 focused ion beam scanning electron microscope multi-beam platform coupled with Oxford X-MaxN energy-dispersive X-ray spectroscopy system. GIS gas injection system, SE secondary electron

perchloric acid $\left(\mathrm{HClO}_{4}\right)$ was added into the cooled mixture. Then, the mixture was digested at $200{ }^{\circ} \mathrm{C}$ in the incubator until the volume was halved. Digested materials were vortexed and diluted in water to a total volume of $10 \mathrm{ml}$. Concentrations were given in micrograms per gram $(\mu \mathrm{g} / \mathrm{g})$ wet tissue weight [41].

All glassware were maintained at 10\% (volume/volume; $\mathrm{v} / \mathrm{v}) \mathrm{HNO}_{3}$ before use, cleaned with deionized water, and dried in an incubator at $100{ }^{\circ} \mathrm{C}$ overnight. $\mathrm{Pb}, \mathrm{Cd}, \mathrm{Cu}, \mathrm{Cr}$, $\mathrm{Fe}, \mathrm{Mn}, \mathrm{Se}$, and $\mathrm{Zn}$ elements were detected by inductively coupled plasma optical emission spectrophotometer (ICP-OES 6000, Thermo, Cambridge, United Kingdom). Measurements for each element were done three times and averaged. The ICP-OES was operated with argon carrier flow rate of $0.5 \mathrm{~L} /$ minute, plasma gas flow rate of $15 \mathrm{~L} /$ minute, sample flow and elusion rate of $1.51 \mathrm{~L} /$ minute, and peristaltic pump speed of $100 \mathrm{rpm}$, selecting the suitable wavelength for $\mathrm{Pb}, \mathrm{Cd}, \mathrm{Cr}, \mathrm{Cu}, \mathrm{Fe}, \mathrm{Mn}, \mathrm{Se}$, and $\mathrm{Zn}$, which were $220.353 \mathrm{~nm}, 228.802 \mathrm{~nm}$, $267.716 \mathrm{~nm}, 324.75 \mathrm{~nm}, 285.213 \mathrm{~nm}, 357.610 \mathrm{~nm}$, $196.090 \mathrm{~nm}$, and $206.200 \mathrm{~nm}$, respectively. Transport lines were obtained using $1.25 \mathrm{~mm}$ internal diameter polytetrafluoroethylene tubing. Element levels were indicated in micrograms per deciliter for serum $(\mu \mathrm{g} / \mathrm{dl})$ and $\mu \mathrm{g} / \mathrm{g}$ for wet tissue. The standard concentrations for standard graph calibration were arranged from standard stock solutions of $1000 \mu \mathrm{g} / \mathrm{ml}$ for each analyzed element [42].

\section{SAM results}

The tissue samples were investigated by using AI mode of SAM. Figure 6 shows the AI map of the tissue obtained away from the gunshot. The map was constructed

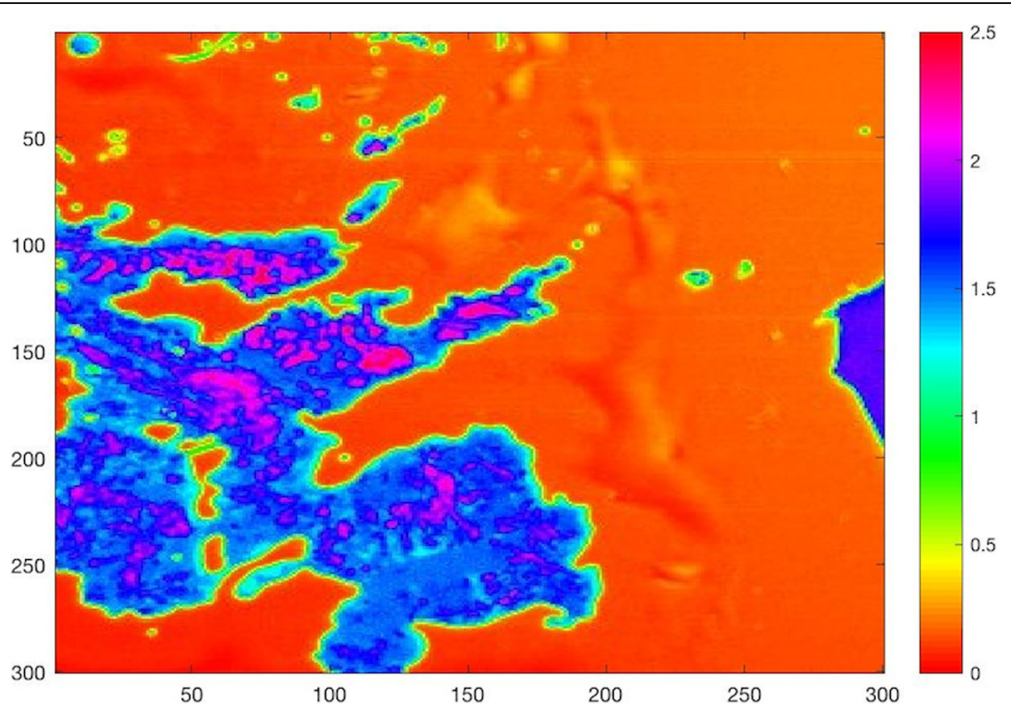

Fig. 6 Acoustic impedance map of the tissue obtained away from the gunshot by comparing the reflected ultrasound signals from the surfaces of water and the sample 


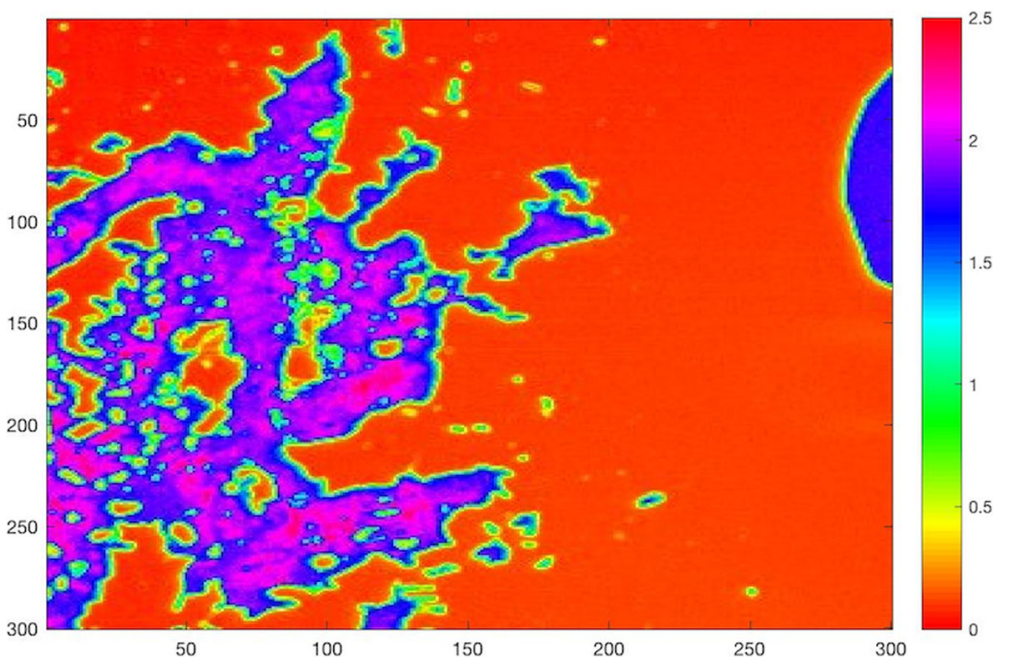

Fig. 7 Acoustic impedance map of the tissue obtained close to the gunshot by comparing the reflected ultrasound signals from the surfaces of water and the sample

by collecting the reflections of acoustic signals, generated by the transducer within SAM, from surfaces of the reference (water) and the tissue sample on the polystyrene substrate. At specific locations within the sample, the AI was calculated to be higher than 2 MRayl, indicating accumulation of elements with different elastic properties. Figure 7 shows the AI map of the tissue obtained close to the gunshot. As can be seen in this image, almost everywhere had an $\mathrm{AI}$ of greater than 2 MRayl.

\section{SEM and EDS results}

SEM images of the tissue far away from the gunshot were obtained at magnifications of $5000 \times$ and $500 \times$, as shown in Figs. 8 and 9, respectively. Similarly, SEM

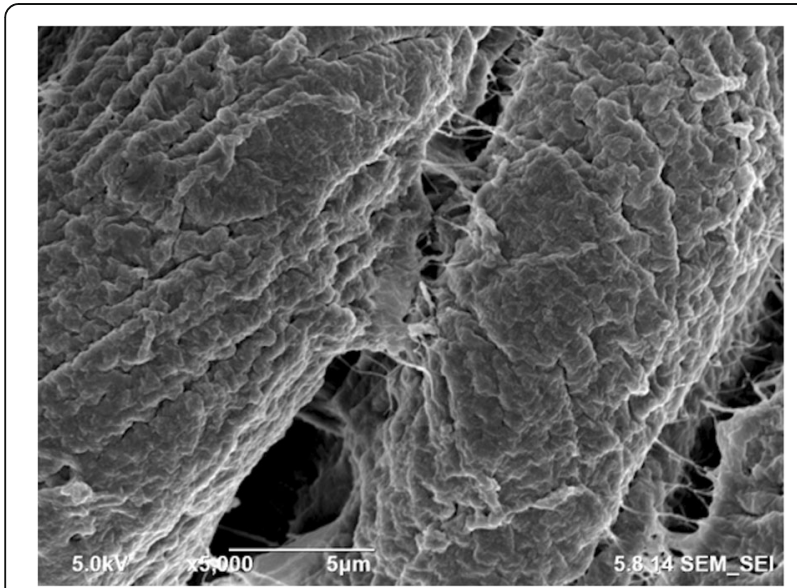

Fig. 8 Scanning electron microscopy image of the tissue obtained away from the gunshot with $5000 \times$ magnification. The tissue seems more or less intact since less damage occurred in this region images for the tissue close to the gunshot were obtained at magnifications of $5000 \times$ and $500 \times$, as shown in Figs. 10 and 11, respectively. The images were acquired at $5 \mathrm{keV}$ energy for both tissue samples.

The SEM images show that the tissue far away from the gunshot keeps its original structure, whereas the tissue close to the gunshot seems to be deformed and torn up. These results demonstrate the degree of damage the impact of gunshot causes on soft biological tissues.

Table 1 represents the EDS measurements in SEM, carried out for determining the elemental distribution differences in the deformed tissues. The measurements show the percentages of the residue elements detected on tissues far away from the gunshot and close to the gunshot. According to the results, among all residue

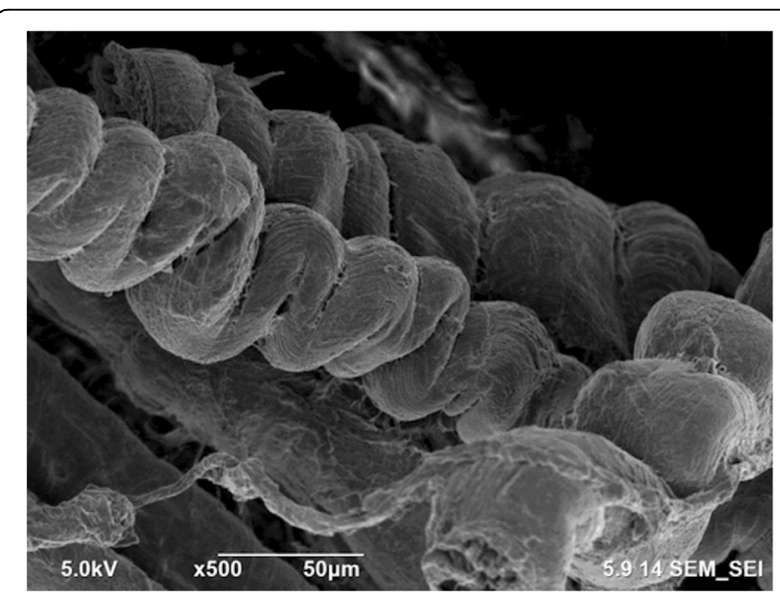

Fig. 9 Scanning electron microscopy image of the tissue obtained away from the gunshot with $500 \times$ magnification. The tissue keeps its original structure with aligned tendons 


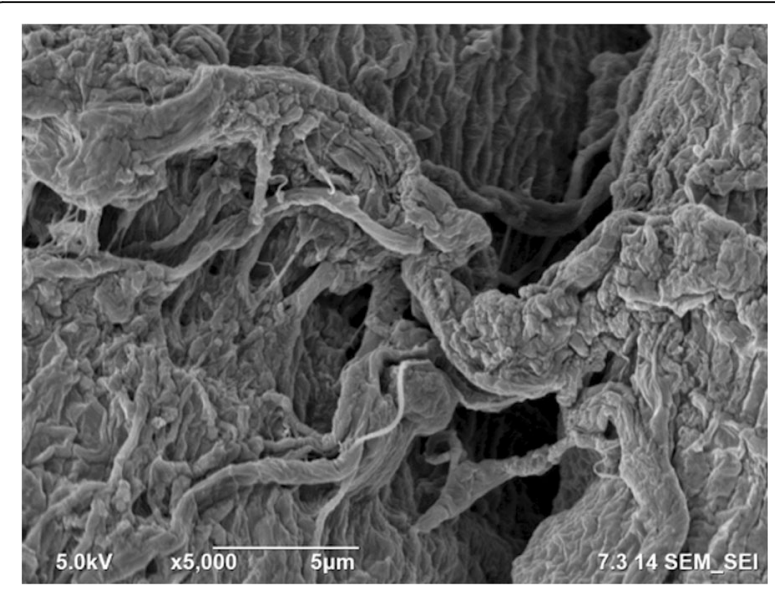

Fig. 10 Scanning electron microscopy image of the tissue obtained close to the gunshot with $5000 \times$ magnification. Due to the damage caused by gunshot impact, the tissue seems torn

elements, $\mathrm{Pb}, \mathrm{Cr}, \mathrm{Fe}$, and $\mathrm{Mn}$ are found to be higher in weight content in the region close to the gunshot, when compared to distant region. $\mathrm{Cd}$ and $\mathrm{Cu}$ levels do not differ much; however, $\mathrm{Zn}$ level is lower in the tissue close to the gunshot.

\section{Element analysis results}

We determined $\mathrm{Pb}, \mathrm{Cr}, \mathrm{Cd}, \mathrm{Cu}, \mathrm{Fe}, \mathrm{Mn}, \mathrm{Zn}$, and Se levels in both tissue samples. $\mathrm{Pb}, \mathrm{Cr}, \mathrm{Fe}, \mathrm{Se}$, and $\mathrm{Mn}$ levels were higher in the tissue close to the gunshot, conversely, $\mathrm{Zn}$ level was lower in this sample (Table 2). Blood $\mathrm{Pb}$ and blood $\mathrm{Cd}$, and serum $\mathrm{Cr}, \mathrm{Cu}, \mathrm{Fe}, \mathrm{Mn}, \mathrm{Se}$, and $\mathrm{Zn}$ levels of our patient were also analyzed and the results are shown in Table 3, however, we did not observe significant differences when compared to reference values.

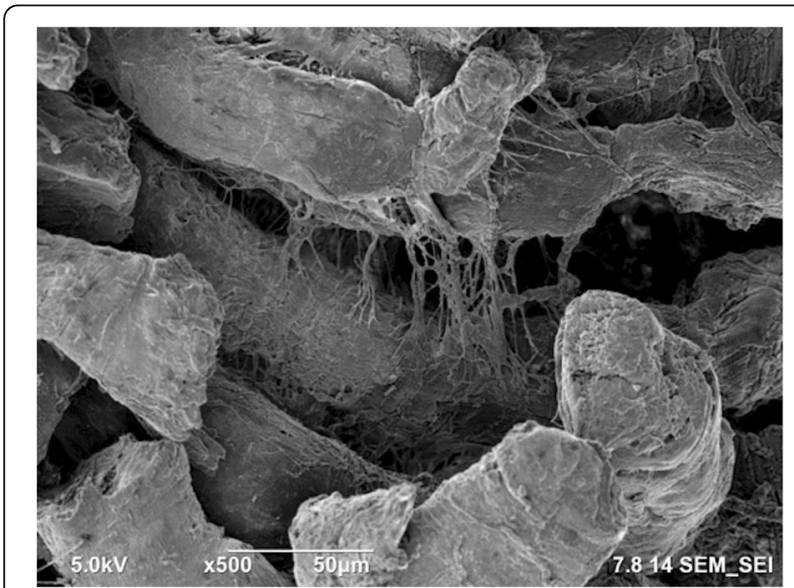

Fig. 11 Scanning electron microscopy image of the tissue obtained close to the gunshot with $500 \times$ magnification. Tendons are not in the form of straight arrays
Table 1 Energy-dispersive X-ray spectroscopy analysis results. The measurements show the weight percentages of the residue elements within the tissues

\begin{tabular}{llllllll}
\hline Tissue & $\mathrm{Cr}$ & $\mathrm{Mn}$ & $\mathrm{Fe}$ & $\mathrm{Cu}$ & $\mathrm{Zn}$ & $\mathrm{Cd}$ & $\mathrm{Pb}$ \\
\hline Close to the gunshot & 0.54 & 1.15 & 1.72 & 10.70 & 41.46 & 1.05 & 42.22 \\
Away from the gunshot & 0.00 & 0.45 & 0.85 & 11.95 & 45.21 & 3.22 & 36.13
\end{tabular}

$\mathrm{Cd}$ cadmium, $\mathrm{Cr}$ chromium, $\mathrm{Cu}$ copper, $\mathrm{Fe}$ iron, $\mathrm{Mn}$ manganese, $\mathrm{Pb}$ lead, $\mathrm{Zn}$ zinc

\section{Discussion}

Foreign bodies such as bullets, shotgun pellets, and shrapnel can cause clinical symptoms by mechanical compression [43], lumen obstruction [44], irritation of nearby structures [45], systemic heavy metal intoxication [5], or tumor formation [46-49]. The first report of the systemic toxicity of the retained bullet dates back to the eighteenth century. Usually, metallic objects embedded into the soft tissue become encapsulated and do not release metals into systemic circulation. However, there are exceptions to this rule [45]. Missiles close to bone, especially if a fracture is present, are prone to systemic toxicity [50]. It is thought that initial impact with bone, fragments the missile with subsequent release [7]. Missiles lodged in or close to joints and intervertebral disks are continuously bathed with synovial fluid, which eventually washes off $\mathrm{Pb}$ from the bullets resulting in systemic toxicity [51-55]. Females are especially vulnerable to this form of toxicity [56]. It is logical to assume that the anatomical structures in close proximity to the retained bullets will suffer the most. For example, one study has demonstrated that bone fracture healing is impaired if there is a foreign metallic bullet [57]. Local metallosis is a well-known complication of metallic implants due to deposition of metallic parts and building up in the soft tissues [58]. Metallosis has been shown to affect nearby neural structures by causing granuloma/pseudotumor formation with mechanical compression [59-64].

Table 2 Element levels within the tissues

\begin{tabular}{lll}
\hline Element & Tissue close to the gunshot & Tissue away from the gunshot \\
\hline $\mathrm{Pb}(\mu \mathrm{g} / \mathrm{g})$ & 1.4716 & 0.0820 \\
$\mathrm{Cd}(\mu \mathrm{g} / \mathrm{g})$ & 0.0355 & 0.0365 \\
$\mathrm{Cr}(\mu \mathrm{g} / \mathrm{g})$ & 1.613 & 0.0520 \\
$\mathrm{Cu}(\mu \mathrm{g} / \mathrm{g})$ & 1.418 & 1.281 \\
$\mathrm{Fe}(\mu \mathrm{g} / \mathrm{g})$ & 1462.057 & 53.829 \\
$\mathrm{Mn}(\mu \mathrm{g} / \mathrm{g})$ & 2.677 & 0.205 \\
$\mathrm{Se}(\mu \mathrm{g} / \mathrm{g})$ & 0.816 & 0.178 \\
$\mathrm{Zn}(\mu \mathrm{g} / \mathrm{g})$ & 33.440 & 39.011
\end{tabular}

$\mathrm{Cd}$ cadmium, $\mathrm{Cr}$ chromium, $\mathrm{Cu}$ copper, $\mathrm{Fe}$ iron, $\mathrm{Mn}$ manganese, $\mathrm{Pb}$ lead, $\mathrm{Se}$ selenium, $Z n$ zinc 
Table 3 Element levels within blood and serum

\begin{tabular}{lll}
\hline Element & Results & References \\
\hline Blood Pb $(\mu \mathrm{g} / \mathrm{dl})$ & 4.16 & $0-40$ \\
Blood $\mathrm{Cd}(\mu \mathrm{g} / \mathrm{dl})$ & 0.04 & $0-10$ \\
Serum $\mathrm{Cr}(\mu \mathrm{g} / \mathrm{dl})$ & 0.40 & $5-50$ \\
Serum Cu $(\mu \mathrm{g} / \mathrm{dl})$ & 126.25 & $70-140$ \\
Serum Fe $(\mu \mathrm{g} / \mathrm{dl})$ & 44.70 & $80-180$ \\
Serum $\mathrm{Mn}(\mu \mathrm{g} / \mathrm{dl})$ & 0.15 & $0.04-0.35$ \\
Serum $\mathrm{Se}(\mu \mathrm{g} / \mathrm{dl})$ & 14.75 & $7-13$ \\
Serum Zn $(\mu \mathrm{g} / \mathrm{dl})$ & 27.95 & $70-120$ \\
\hline
\end{tabular}

$\mathrm{Cd}$ cadmium, $\mathrm{Cr}$ chromium, $\mathrm{Cu}$ copper, $\mathrm{Fe}$ iron, $\mathrm{Mn}$ manganese, $\mathrm{Pb}$ lead, $\mathrm{Se}$ selenium, $Z n$ zinc

In SAM images, the AI increased as the distance between the metallic body and the tissue sample decreased, which is evidence of $\mathrm{Pb}$ mobilization from a gunshot. Heavy metals accumulated in the tissue increases the elasticity, therefore, the AI of the tissue. In the tissue close to the gunshot, the AI was measured to be higher than 2 MRayl almost everywhere, while, in the tissue away from the gunshot, the AI was greater than 2 MRayl only at certain locations. SEM images demonstrate that the tissue obtained far away from the gunshot is found to keep its original structure, whereas the tissue obtained near to the gunshot is deformed and torn up. EDS and ICP-OES results show that $\mathrm{Pb}, \mathrm{Fe}, \mathrm{Cr}$, and $\mathrm{Mn}$ levels are found to be higher in the region close to the gunshot when compared to the distant region. The differences in elemental composition in both regions can also play a role in changing the morphology of tissues. Elements measured in blood and serum do not express an apparent residue mobilization since it has been found that during the first 6 months after a trauma, there was a tendency of blood $\mathrm{Pb}$ level elevation and then stabilization after that period [7]. In the literature, we came across no data on the relationship between trace and toxic elements in the gluteal area with one metallic pellet close to the sciatic nerve and our results pointed out that $\mathrm{Pb}$ mobilizes from the gunshot into the tissues of the critical organs and changes the concentrations of elements such as $\mathrm{Fe}, \mathrm{Cr}, \mathrm{Mn}$, and $\mathrm{Zn}$ in these organs.

Our findings indicate that tissues closest to metallic bullets suffer from local metallosis. We cannot be absolutely sure about the leading cause of neuropathy in our patient; however, no improvement after the first surgery for lumbar disc herniation indicated another factor. She had local tenderness in the deep gluteal area, which is a sign of sciatic nerve injury. Another possibility was that she suffered from "double hit" where sciatic nerve injury compression aggravated each other. We did not try to obtain a biopsy from the sciatic nerve since it causes damage to a nerve with subsequent neurological deterioration.

\section{Conclusion}

In this study, we present the capability of SAM, SEM, EDS, and ICP-OES in determining the metal toxicity in tissues due to a gunshot injury for the first time. SAM maps of the tissues show morphological and chemical differences at differing distances to the metallic body. SEM and EDS results confirm SAM results by obtaining dissimilar images and elemental distributions for these tissues. Element analysis by ICP-OES also shows explicitly different element levels within the tissues. Consequently, we can say that SAM is capable of observing metal mobilization from a gunshot into the tissues.

\section{Acknowledgements}

We are thankful to the patient, who gave us permission to study her tissues, and to the Ministry of Development of Turkey, who supported the scanning acoustic microscopy studies in this research.

\section{Funding}

This study was funded by the Ministry of Development of Turkey (grant number 2009 K120520).

\section{Availability of data and materials \\ The datasets used and/or analyzed during the current study are available from the corresponding author on reasonable request.}

Authors' contributions

BB started and led this study, also, conducted the SAM experiments. MS conducted the SEM and EDS experiments. FAA did the trace element analysis. BB, MS, FAA, and UBB analyzed the corresponding results. KA did the surgeries and provided the tissues. BB, MBU, and KA wrote the paper. All authors reviewed the manuscript. All authors read and approved the final manuscript.

Ethics approval and consent to participate

All procedures performed in studies involving human participants were in accordance with the ethical standards of Biruni University Hospital research committee and with the 1964 Helsinki Declaration and its later amendments or comparable ethical standards. Written informed consent to participate in this study was obtained from the participant.

\section{Consent for publication}

Written informed consent was obtained from the patient for publication of this case report and any accompanying images. A copy of the written consent is available for review by the Editor-in-Chief of this journal.

\section{Competing interests}

The authors declare that they have no competing interests.

\section{Publisher's Note}

Springer Nature remains neutral with regard to jurisdictional claims in published maps and institutional affiliations.

\section{Author details}

${ }^{1}$ Physics Department, Bogazici University, Istanbul, Turkey. ${ }^{2}$ Biophysics Department, Faculty of Medicine, Beykent University, Istanbul, Turkey. ${ }^{3}$ Biophysics Department, Cerrahpasa Faculty of Medicine, Istanbul University, Istanbul, Turkey. ${ }^{4}$ Sabanci University Nanotechnology Research and Application Center, Sabanci University, Istanbul, Turkey. ${ }^{5}$ Biruni University Hospital, Istanbul, Turkey. 


\section{Received: 18 September 2018 Accepted: 29 October 2018} Published online: 28 December 2018

\section{References}

1. Bolanos AA, Demizio JP Jr, Vigorita VJ, Bryk E. Lead poisoning from an intra-articular shotgun pellet in the knee treated with arthroscopic extraction and chelation therapy. A case report. J Bone Joint Surg Am. 1996;78(3):422-6.

2. Wu PB, Kingery PB, Date ES. An EMG case report of lead neuropathy 19 years after a shotgun injury. Muscle Nerve. 1995;18(3):326-9.

3. Farrell SE, Vandevander P, Schoffstall JM, Lee DC. Blood lead levels in emergency department patients with retained lead bullets and shrapnel. Acad Emerg Med. 1999;6(3):208-12.

4. Aly MH, Kim HC, Renner SW, Boyarsky A, Kosmin M, Paglia DE. Hemolytic anemia associated with lead poisoning from shotgun pellets and the response to Succimer treatment. Am J Hematol. 1993;44(4):280-3.

5. Linden MA, Manton WI, Steward RM, Thal ER, Feit H. Lead poisoning from retained bullets. Pathogenesis, diagnosis, and management. Ann Surg. 1982; 195(3):305-13

6. Abraham A, Singh J, Mustacchia P, Rizvon K. Pain from a bullet lingers on: an uncommon case of lead toxicity. Case Rep Gastroenterol. 2012; 6(2):243-8.

7. McQuirter JL, Rothenberg SJ, Dinkins GA, Kondrashov V, Manalo M, Todd AC. Change in blood lead concentration up to 1 year after a gunshot wound with a retained bullet. Am J Epidemiol. 2004;159(7):683-92.

8. Sanborn MD, Abelson A, Campbell M, Weir E. Identifying and managing adverse environmental health effects: 3. Lead exposure. Can Med Assoc J. 2002;166(10):1287-92.

9. Dillman RO, Crumb CK, Lidsky MJ. Lead poisoning from a gunshot wound Report of a case and review of the literature. Am J Med. 1979;66(3):509-14.

10. Dasani BM, Kawasanishi $\mathrm{H}$. The gastrointestinal manifestations of gunshotinduced lead poisoning. J Clin Gastroenterol. 1994;19(4):296-9.

11. Fiorica V, Brinker JE. Increased lead absorption and lead poisoning from a retained bullet. J Okla State Med Assoc. 1989;82(2):63-7.

12. Scuderi GJ, Vaccaro AR, Fitzhenry LN. Long-term clinical manifestations of retained bullet fragments within the intervertebral disk space. J Spinal Disord Tech. 2004;17(2):108-11.

13. Coon T, Miller M, Shirazi F, Sullivan J. Lead toxicity in a 14-year-old female with retained bullet fragments. Pediatrics. 2006;117(1):227-30.

14. John BE, Boatright D. Lead toxicity from gunshot wound. South Med J. 1999;92(2):223-4

15. Nguyen A, Schaider JJ, Manzanares M, Hanaki R, Rydman RJ, Bokhari F Elevation of blood lead levels in emergency department patients with extra-articular retained missiles. J Trauma. 2005;58(2):289-99.

16. Roux P, Pocock F. Blood lead concentration in children after gunshot injuries. S Afr Med J. 1988;73(10):580-2.

17. Nowak B, Chmielnicka J. Relationship of lead and cadmium to elements in hair, teeth, and nails of environmentally exposed people. Ecotoxicol Environ Saf. 2000;46(3):265-74

18. Miura K, Egawa Y, Moriki T, Mineta H, Harada H, Baba S, et al. Microscopic observation of chemical modification in sections using scanning acoustic microscopy. Pathol Int. 2015;65(7):355-66.

19. Saijo Y, Filho ES, Sasaki H, Yambe T, Tanaka M, Hozumi N, et al. Ultrasonic tissue characterization of atherosclerosis by a speed-of-sound microscanning system. IEEE Trans Ultrason Ferroelectr Freq Control. 2007; 54(8):1571-7.

20. Akhtar R, Cruickshank JK, Zhao X, Derby B, Weber T. A pilot study of scanning acoustic microscopy as a tool for measuring arterial stiffness in aortic biopsies. Artery Res. 2016;13:1-5.

21. Saijo Y, Hozumi N, Lee C, Nagao M, Kobayashi K, Oakada N, et al. Ultrasonic speed microscopy for imaging of coronary artery. Ultrasonics. 2006;44:e51-5.

22. Miura K, Katoh H. Structural and histochemical alterations in the aortic valves of elderly patients: a comparative study of aortic stenosis, aortic regurgitation, and normal valves. Biomed Res Int. 2016;2016:6125204.

23. Brewin MP, Srodon PD, Greenwald SE, Birch MJ. Carotid atherosclerotic plaque characterization by measurement of ultrasound sound speed in vitro at high frequency, $20 \mathrm{MHz}$. Ultrasonics. 2014;54(2):428-41.

24. Saijo Y, Miyakawa T, Sasaki H, Tanaka M, Nitta S. Acoustic properties of aortic aneurysm obtained with scanning acoustic microscopy. Ultrasonics. 2004; 42(1-9):695-8.
25. Saijo Y, Ohashi T, Sasaki H, Sato M, Jorgensen CS, Nitta S. Application of scanning acoustic microscopy for assessing stress distribution in atherosclerotic plaque. Ann Biomed Eng. 2001;29(12):1048-53.

26. Miura K, Nasu H, Yamamoto S. Scanning acoustic microscopy for characterization of neoplastic and inflammatory lesions of lymph nodes. Sci Rep. 2013:3:1255.

27. Miura K, Yamamoto S. Pulmonary imaging with a scanning acoustic microscope discriminates speed-of-sound and shows structural characteristics of disease. Lab Investig. 2012;92(12):1760-5.

28. Kobayashi K, Yoshida S, Saijo Y, Hozumi N. Acoustic impedance microscopy for biological tissue characterization. Ultrasonics. 2014;54(7):1922-8.

29. Hatori K, Saijo Y, Hagiwara Y, Naganuma Y, lgari K, likubo M, et al. Acoustic diagnosis device for dentistry. In: Interface Oral Health Science 2016; 2017. https://doi.org/10.1007/978-981-10-1560-1_16.

30. Strohm EM, Czarnota GJ, Kolios MC. Quantitative measurements of apoptotic cell properties using acoustic microscopy. IEEE Trans Ultrason Ferroelectr Freq Control. 2010;57(10):2293-304.

31. Shelke A, Brand S, Kundu T, Bereiter-Hahn J, Blase C. Mechanical property quantification of endothelial cells using scanning acoustic microscopy. Proc SPIE. 2012;8348:83481T.

32. Brand S, Czarnota GJ, Kolios MC, Weiss EC, Lemor R. Visualization of apoptotic cells using scanning acoustic microscopy and high frequency ultrasound. Proc IEEE Int Ultrason Symp. 2005;2:882-5.

33. Masugata H, Mizushige K, Senda S, Kinoshita A, Lu X, Sakamoto H, et al. Tissue characterization of myocardial cells by use of high-frequency acoustic microscopy: differential myocyte sound speed and its transmural variation in normal, pressure-overload hypertrophic, and amyloid myocardium. Angiology. 1999;50(10):837-45

34. Miura K, Yamamoto S. A scanning acoustic microscope discriminates cancer cells in fluid. Sci Rep. 2015:5:15243.

35. Strohm EM, Kolios MC. Quantifying the ultrasonic properties of cells during apoptosis using time resolved acoustic microscopy. Proc IEEE Int Ultrason Symp. 2009. https://doi.org/10.1109/ultsym.2009.5441810

36. Saijo $Y$, Sasaki $H$, Sato M, Nitta S, Tanaka M. Visualization of human umbilical vein endothelial cells by acoustic microscopy. Ultrasonics. 2000;38(1-8):396-69.

37. Soon TTK, Chean TW, Yamada H, Takahashi K, Hozumi N, Kobayashi K, et al. Effects of anticancer drugs on glia-glioma brain tumor model characterized by acoustic impedance microscopy. Jpn J Appl Phys. 2017;56:07JF15.

38. Romolo FS, Margot P. Identification of gunshot residue: a critical review. Forensic Sci Int. 2001;119(2):195-211.

39. Chohra M, Baladel B, Ahmed LB, Mouzai M, Akretche D, Zeghdaoui A, et al. Study of gunshot residue by NAA and ESEM/EDX using several kinds of weapon and ammunition. J Radiat Res Appl Sci. 2015;8(3):404-10.

40. Ates Alkan F, Karis D, Cakmak G, Ercan AM. Analysis of the relationship between hemorheologic parameters, aluminum, manganese, and selenium in smokers. Biol Trace Elem Res. 2018. https://doi.org/10.1007/s12011-018$1352-8$

41. Cetin H, Nazirogu M, Celik O, Yuksel M, Pastaci N, Ozkaya MO. Liver antioxidant stores protect the brain from electromagnetic radiation (900 and $1800 \mathrm{MHz}$ )-induced oxidative stress in rats during pregnancy and the development of offspring. J Matern Fetal Neonatal Med. 2014; 27(18):1915-21.

42. Bursalioglu EO, Ates Alkan F, Barutcu UB, Demir M, Karabul Y, Balkan B, et al. Prediction of electron density and trace element concentrations in human blood serum following radioiodine therapy in differentiated thyroid cancer patients. Measurement. 2017;100:19-25.

43. Link MJ, Driscoll CL, Esquenazi Y. Vagoglossopharyngeal-associated syncope due to a retained bullet in the jugular foramen. Skull Base. 2010;20(2):105-9.

44. Mincheff TV. Bullet fragment within the appendix: a case report. J S C Med Assoc. 2004;100(10):270-3.

45. Eylon S, Mosheiff R, Liebergall M, Wolf E, Brocke L, Peyser A. Delayed reaction to shrapnel retained in soft tissue. Injury. 2005;36(2):275-81.

46. Ebrahimzadeh MH, Vahedi E, Ganji R, Bozorgnia S. Skeletal sarcoma on the site of retained war bullet fragments and a literature review on long-term complications of retained war shells. Arch Bone Jt Surg. 2013;1(2):107-11.

47. Keel SB, Jaffe KA, Petur Nielsen G, Rosenberg AE. Orthopaedic implantrelated sarcoma: a study of twelve cases. Mod Pathol. 2001;14(10):969-77.

48. Hanzawa S, Wada G. Pulmonary squamous cell carcinoma developing around old bullet wound. Nihon Kyobu Geka Gakkai Zasshi. 1983:31(8): 1325-9. 
49. Schmitt HP. Trauma and tumor: malignant glioma in the area of a traumatic lesion of the brain with metal scales. Fortschr Neurol Psychiatr. 1983;51(6): 227-31.

50. McQuirter UL, Rothenberg SJ, Dinkins GA, Manalo M, Kondrashov V, Todd AC. The effects of retained lead bullets on body lead burden. FJ Trauma. 2001:50(5):892-9.

51. Slavin RE, Swedo J, Cartwright I Jr, Viegas S, Custer EM. Lead arthritis and lead poisoning following bullet wounds: a clinicopathologic, ultrastructural, and microanalytic study of two cases. Hum Pathol. 1988;19(2):223-35.

52. Scafani SJ, Vuletin JC, Twersky J. Lead arthropathy: arthritis caused by retained intra-articular bullets. Radiology. 1985;156(2):299-302.

53. Meggs WJ, Gerr F, Aly MH, Kierena T, Roberts DL, Shih R, et al. The treatment of lead poisoning from gunshot wounds with succimer (DMSA). J Toxicol Clin Toxicol. 1994;32(4):377-85.

54. Cristante AF, de Souza Fl, Barros Filho TE, Oliveira RP, Marcon RM. Lead poisoning by intradiscal firearm bullet: a case report. Spine (Phila Pa 1976). 2010:35(4):E140-3.

55. Gameiro VS, de Araujo GC, Bruno FM. Lead intoxication and knee osteoarthritis after a gunshot: long-term follow-up case report. BMJ Case Rep. 2013;2013:bcr2013009404.

56. Porter $S$, Hanley E, Sing RF. Fetal anomalies resulting from maternal bulletrelated plumbism. J Trauma Acute Care Surg. 2004;56(6):1173-8.

57. Riehl JT, Connolly K, Haidukewych G, Koval K. Fractures due to gunshot wounds: do retained bullet fragments affect union? lowa Orthop J. 2015;35: 55-61.

58. Goldenberg Y, Tee JW, Salinas-La Rosa CM, Murphy M. Spinal metallosis: a systematic review. Eur Spine J. 2016;25(5):1467-73.

59. Takahashi S, Delecrin J, Passuti N. Intraspinal metallosis causing delayed neurologic symptoms after spinal instrumentation surgery. Spine (Phila Pa 1976). 2001;26(13):1495-8.

60. Pai VS, Patel N. Rare case of sciatic nerve palsy in a modular total hip arthroplasty. J Arthroplast. 2001;16(4):512-4.

61. Kuijlen JM, Herpers MJ, Beuls EA. Neurogenic claudication, a delayed complication of a retained bullet. Spine (Phila Pa 1976). 1997;22(8):910-4.

62. Harvie P, Torres-Grau J, Beaver RJ. Common peroneal nerve palsy associated with pseudotumour after total knee arthroplasty. Knee. 2012;2:148-50.

63. Conway JE, Crofford TW, Terry AF, Protzman RR. Cauda equina syndrome occurring nine years after a gunshot injury to the spine. A case report. J Bone Joint Surg Am. 1993;75(5):760-3.

64. Rentfrow B, Vaidya R, Elia C, Sethi A. Lead toxicity and management of gunshot wounds in the lumbar spine. Eur Spine J. 2013;22(11):2353-7.

Ready to submit your research? Choose BMC and benefit from:

- fast, convenient online submission

- thorough peer review by experienced researchers in your field

- rapid publication on acceptance

- support for research data, including large and complex data types

- gold Open Access which fosters wider collaboration and increased citations

- maximum visibility for your research: over $100 \mathrm{M}$ website views per year

At BMC, research is always in progress.

Learn more biomedcentral.com/submissions 